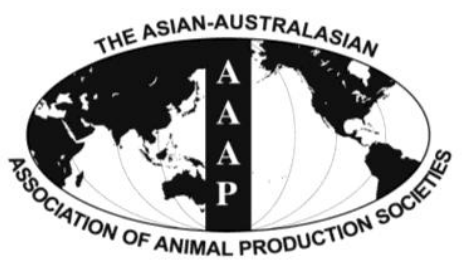

Asian-Aust. J. Anim. Sci.

Vol. 26, No. 1 : 72-81 January 2013

http://dx.doi.org/10.5713/ajas.2012.12277

www.ajas.info

pISSN 1011-2367 elSSN 1976-5517

\title{
Effects of Soybean Small Peptides on Rumen Fermentation and on Intestinal and Total Tract Digestion of Luxi Yellow Cattle
}

\author{
W. J. Wang ${ }^{2,3}$, W. R. Yang ${ }^{2}$, Y. Wang ${ }^{4}$, E. L. Song ${ }^{1,3}$, X. M. Liu ${ }^{1,3}$ and F. C. Wan ${ }^{1,3, *}$ \\ ${ }^{1}$ Institute of Animal Science Veterinary Medicine, Shandong Academy of Agricultural Sciences, \\ Jinan, Shandong, 250100, China
}

\begin{abstract}
Four Luxi beef cattle $(400 \pm 10 \mathrm{~kg})$ fitted with ruminal, duodenal and ileal cannulas were used in a $4 \times 4$ Latin square to assess the effects of soybean small peptide (SSP) infusion on rumen fermentation, diet digestion and flow of nutrient in the gastrointestinal tract. The ruminal infusion of SSP was 0 (control), 100, 200 and $300 \mathrm{~g} / \mathrm{d}$. Ruminal SSP infusion linearly (p<0.01) and quadratically $(\mathrm{p}<0.01)$ increased microbial protein synthesis and rumen ammonia-N concentration. Concentrations of total volatile fatty acid were linearly increased $(\mathrm{p}=0.029)$ by infusion SSP. Rumen samples were obtained for analysis of microbial ecology by real-time PCR. Populations of rumen Butyrivibrio fibrisolvens, Streptococcus bovis, Ciliate protozoa, Ruminococcus flavefaciens, and Prevotella ruminicola were expressed as a proportion of total Rumen bacterial $16 \mathrm{~S}$ ribosomal deoxyribonucleic acid (rDNA). Butyrivibrio fibrisolvens populations which related to total bacterial $16 \mathrm{~S}$ rDNA were increased $(\mathrm{p}<0.05)$, while Streptococcus bovis populations were linearly $(\mathrm{p}=0.049)$ and quadratically $(\mathrm{p}=0.020)$ decreased by infusion of SSP. Apparent rumen digestibility of DM and NDF were $(Q$, $\mathrm{p}<0.05 ; L, \mathrm{p}<0.05)$ increased with infusion SSP. Total tract digestion of DM, OM and NDF were linearly $(\mathrm{p}<0.01)$ and quadratically $(\mathrm{p}<0.01)$ increased by infusing SSP. The flow of total amino acids (AA), essential amino acids (EAA) and individual amino acids were linearly $(p<0.01)$ and quadratically $(p<0.01)$ increased with infusion SSP. The digestibility of Lysine was quadratically $(p=0.033)$ increased and apparent degradability of Arginine was linearly $(p=0.032)$ and quadratically $(p=0.042)$ increased with infusion SSP. The results indicated that infusion SSP could improve nutrient digestion, ruminal fermentation and AA availability. (Key Words: Cattle, Digestibility, Flow, Microbial, Rumen Fermentation, Soybean Small Peptide)
\end{abstract}

\section{INTRODUCTION}

It has been demonstrated that rumen bacteria use both ammonia-N and non-ammonia-N (NAN; e.g. amino acid, peptides) for bacterial protein synthesis and some species of bacteria prefer NAN to ammonia-N (Russell et al., 1992; Cruz Soto et al., 1994; Griswold et al., 1996). Lindemann et al. (2000) and Dabrowski et al. (2003) showed that supplying peptides offered an advantage over free AA that is easily deaminated in the rumen. However, discrepant results were reported from in vitro studies that assessed the

\footnotetext{
* Corresponding Author: F. C. Wan. Tel: +86-0531-831-79947, Fax: +86-0531-889-78476, E-mail: wanfc@ sina.com.cn

2 Department of Animal Sciences and Technology, Shandong Agricultural University, Tai-an, Shandong, 271018, China.

3 Shandong Key Laboratory of Animal Disease Control and Breeding, Jinan, Shandong, 250100, China.

${ }^{4}$ Agriculture and Agri-Food Canada, Lethbridge Research Centre, PO Box 3000, Lethbridge, Alberta, Canada, T1J4

Submitted May 19, 2012; Accepted Sept. 11, 2012; Revised Sept. 17, 2012
}

effects of peptides on the rumen metabolism. Whilst some studies showed that rumen bacteria growth, fibre digestion and overall rumen fermentation were improved by supplementation of peptides (Griswold et al., 1996; Carro and Miller, 1999; Russi et al., 2002), this was not observed in other studies (Cruz Soto et al., 1994; Jones et al., 1998). However, there is little information about the effects of supplementation of peptide on rumen microbial activity and on ruminal metabolism in vivo.

Small peptides obtained from proteolytic hydrolysis of different plant proteins have been shown to have various biological and pharmaceutical activities including enhancing growth performance and immunological status (Kotzamanis et al., 2007), offering a more cost-effective way of supplementing AA (Zimmerman et al., 1997; Lindemann et al., 2000; Dabrowski et al., 2003), improving nitrogen retention (Adibi et al., 1993), and increasing mohair fiber growth (Puchala et al., 2002). Zhang et al. (2007) reported that feeding or duodenal infusing SSP, improved nitrogen balance and protein biological value and 
increased digestibility of dietary nutrients in goats and that supplying SSP by infusing through a duodenum fistula was more efficient than feeding. Liu et al. (2009) also observed increased absorption of small peptides from small the intestine and increased milk protein synthesis by duodenal infusion of SSP. However, information of the effects of SSP on rumen fermentation, microbes and digestive tract metabolism is limited. The objective of this study was to determine the effects of SSP on ruminal fermentation and nutrition digestibility of beef cattle.

\section{MATERIALS AND METHODS}

\section{Experimental design and diets}

The experiment consisted of four treatments and was conducted in a $4 \times 4$ Latin square arrangement using four Luxi Cattle steers (approximate 30 months old) averaging $400 \pm 10 \mathrm{~kg}$ body weight and fitted with ruminal, proximate duodenal (simple T-piece) and terminal ileal cannula. The fistulation procedures and animal care were according to the experimental protocol that was reviewed and approved by Shandong Academy of Agriculture Sciences. Cattle were fed indoors in individual stalls. Each period lasted for $20 \mathrm{~d}$, comprising a 10-d adaptation and 10-d experiment and sampling. The four treatments were basal diet supplemented with SSP which was produced from proteolytic hydrolysis (ZS Duqing Biotech CO., Ltd., Shandong, China) and dosed by ruminal infusion at the levels of $0,100,200$ and $300 \mathrm{~g} / \mathrm{d}$ (denoted as Control, SSP100, SSP200 and SSP300 respectively). The AA composition of the SSP is shown in

Table 1. The concentration $(\mathrm{mg} / \mathrm{g})$ of total amino acids and peptide amino acids in soybean small peptides

\begin{tabular}{lcc}
\hline Items & $\begin{array}{c}\text { Total amino acid } \\
\text { content }\end{array}$ & $\begin{array}{c}\text { Peptide amino acid } \\
\text { content }\end{array}$ \\
\hline Aspartic acid & 90.91 & 89.06 \\
Glutamic acid & 196.10 & 189.48 \\
Serine & 46.60 & 46.06 \\
Histidine & 19.70 & 18.97 \\
Glycine & 32.60 & 32.09 \\
Threonine & 32.00 & 30.72 \\
Arginine & 62.00 & 60.85 \\
Alanine & 34.90 & 32.85 \\
Tyrosine & 27.60 & 26.19 \\
Cystine & 6.70 & 6.19 \\
Valine & 32.00 & 30.65 \\
Methionine & 12.50 & 11.45 \\
Phenylalanine & 38.20 & 35.49 \\
Isoleucine & 30.80 & 30.15 \\
Leucine & 61.10 & 55.77 \\
Lysine & 55.40 & 54.59 \\
Proline & 52.30 & 52.29 \\
TAA ${ }^{1}$ & 831.41 & 802.85 \\
\hline TAA Tota & &
\end{tabular}

${ }^{1}$ TAA $=$ Total amino acids
Table 1. The basal diet (Table 2) was a total mixed ration (TMR) formulated to meet the nutrient requirements of cattle (Feeding Standard of Cattle of the People's Republic of China, NY/T815- 2004). The TMR was offered in equal amount twice daily at 07:00 and 19:00 for 95\% of the ad libitum intake and all cattle had free access to fresh water. The daily amount of SSP of each treatment was dissolved in $1,000 \mathrm{ml}$ of $0.9 \%$ physiological saline and was infused using a peristaltic pump (BL-100, Prefluid Technology Company, Jiangsu, China) into the rumen through the ruminal cannula upon morning feeding from d 11 to $\mathrm{d} 20$ at 7:00 clock everyday. Cattle without SSP were infused $1.0 \mathrm{~L}$ of physiological saline only (Control).

\section{Sampling and preparations}

Samples of feed offered were taken daily during the entire experimental period, composted, oven dried $\left(55^{\circ} \mathrm{C}\right)$ and ground to pass $1.0 \mathrm{~mm}$ screen for chemical analysis. Duodenal and ileal flow and fecal output were measured by $15 \mathrm{~g} / \mathrm{d}$ of chromic oxide (Uden et al., 1980), which was given as three boluses of $2.5 \mathrm{~g}$ each $(7.5 \mathrm{~g}$ twice daily at 07:00 and 19:00 h) and administered into the rumen via fistula before feeding on d 11 through 20 . On d 18 to 20 , samples of duodenal $(300 \mathrm{ml})$ and ileal $(200 \mathrm{ml})$ chyme, faeces (300 $\mathrm{g}$ wet basis) and ruminal fluid $(200 \mathrm{ml})$ from the rumen were collected every $6 \mathrm{~h}$ daily. The sampling time was adjusted $2 \mathrm{~h}$ ahead of the previous day so that samples obtained represented every $2 \mathrm{~h}$ during $24-\mathrm{h}$ period

Table 2. Ingredients and chemical composition of the basal diet (\% DM) fed during the experiment

\begin{tabular}{lr}
\hline Ingredients & Content \\
\hline Chinese wild rye & 61.61 \\
Corn & 27.00 \\
Wheat bran & 2.89 \\
Cottonseed meal & 6.75 \\
Calcium hydrogen phosphate & 0.35 \\
Calcium carbonate & 0.58 \\
Sodium chlorid & 0.39 \\
Sodium bicarbonate & 0.39 \\
Minerals premix ${ }^{2}$ & 0.04 \\
Vitamins preminx ${ }^{2}$ & 0.19 \\
Total & 100.00 \\
Analyzed composition & \\
CP \% & 9.55 \\
ADF \% & 27.68 \\
NDF \% & 52.27 \\
Ca \% & 0.86 \\
Calculated composition & \\
NEm/(MJ/kg) & 6.48 \\
\hline
\end{tabular}

${ }^{1}$ Provides per kg of minerals premix: $40 \mathrm{~g}$ of Mn, $60 \mathrm{~g}$ of $\mathrm{Zn}, 20 \mathrm{~g}$ of Fe, $30 \mathrm{~g}$ of $\mathrm{Cu}, 1.5 \mathrm{~g}$ of I, $1 \mathrm{~g}$ of Se, $400 \mathrm{mg}$ of Co.

${ }^{2}$ Provides per kg of minerals vitamins premix: $30,000,000 \mathrm{IU}$ of vitamin A, 100,000,000 IU of vitamin D, 6,000 mg of vitamin E. 
(12 total samples). The duodenal, ileal and fecal samples were immediately stored at $-20^{\circ} \mathrm{C}$, lyophilized and ground in a Wiley mill to pass a $1.00 \mathrm{~mm}$ screen for laboratory analysis. Sub-samples of rumen fluid were also strained through four layers of cheesecloth, $\mathrm{pH}$ measured immediately using a pH meter (Model PB-20, Sartorius, Germany), and were then stored at $-20^{\circ} \mathrm{C}$ for analysis of ammonia-N, microbial crude protein (MCP) and volatile fatty acids (VFA).

Approximately $200 \mathrm{ml}$ of rumen fluid collected at $6 \mathrm{~h}$ after feeding on $\mathrm{d} 20$ of each period was immediately stored at $-80^{\circ} \mathrm{C}$ for determination of the relative quantity to total bacterial $16 \mathrm{~S}$ rDNA of Butyrivibrio fibrisolvens, Ruminococcus flavefaciens, Ciliate protozoa, Butyrivibrio fibrisolvens and Streptococcus bovis.

\section{Chemical analysis}

Samples were analyzed for total N, DM, OM, Ca and P (AOAC, 1997), and for NDF and ADF (Van Soest et al., 1991). Amino acid analyses were performed according to the methods of the AOAC (1997) using the cationic HPLC system that utilizes post derivatization with ninhydrin followed by UV.

Chromium concentrations of duodenal, ileal, and fecal samples were determined by atomic absorption spectrophotometry with an acetylene/air flame according to the methods of Willams et al. (1962). Rumen fluid samples were analyzed for ammonia $\mathrm{N}$ and VFA concentration using methods described by $\mathrm{Hu}$ et al. (2005) and for MCP by analyzing purine concentration using method described by Zinn and Owens (1986).

Quantification of microbial $16 S$ rRNA marker genes by $R T-P C R$ : Total DNA was extracted from rumen fluid by a SDS-based DNA extraction method as described by Zhou et al. (1996). The primers of total bacteria, ciliate protozoa, Prevotella ruminicoal, Butyrivibrio fibrisolvens, Ruminococcus flavefaciens and Sreptococus bovis are listed in Table 3, as described by Khafipour et al. (2009) and Stuart and McSweeney (2006). The species-specific realtime quantitative PCR was performed using the Roche 4500 real time PCR system with fluorescence detection of SYBR green dye. Amplification conditions were as follows: one cycle at $95^{\circ} \mathrm{C}$ for $30 \mathrm{~s}$ for initial denaturation and followed by 40 cycles of $95^{\circ} \mathrm{C}$ for $5 \mathrm{~s}$ and $60^{\circ} \mathrm{C}$ for $20 \mathrm{~s}$. Specificity of amplified products was confirmed by melting temperature and dissociation curves after each amplification. Amplification efficiencies for each primer pair were investigated by examining dilution series of total ruminal microbial DNA template in triplicate.

\section{Data calculation and statistical analysis}

Duodenal, ileal, and fecal output for each cattle were calculated as the amount of chromic oxide consumed $(\mathrm{g} / \mathrm{d})$ divided by the chromic oxide concentration ( $\mathrm{g} / \mathrm{kg}$ of $\mathrm{DM})$ in the duodenal and ileal chyme or feces (Wang et al., 1998). Nutrient apparently digested in the rumen was calculated as the difference between the nutrient intake $(\mathrm{kg} / \mathrm{d})$ and its duodenal flow $(\mathrm{kg} / \mathrm{d})$. Nutrient apparently digested in the small intestinal was calculated as the difference between the duodenal flow $(\mathrm{kg} / \mathrm{d})$ and ideum flow $(\mathrm{kg} / \mathrm{d})$. Nutrient apparently digested in the large intestinal was calculated as the difference between the ideum flow and fecal output $(\mathrm{kg} / \mathrm{d})$. Nutrient apparently digested in the total tract was calculated as the difference between the intake and fecal output $(\mathrm{kg} / \mathrm{d})$.

The abundance of $16 \mathrm{~S}$ rRNA marker gene copy number for the ciliate protozoa, P. ruminicola, B. fibrisolvens, $R$. flavefacien and S.bovis were expressed relative to the copy number of total rumen bacterial $16 \mathrm{~S}$ rRNA according to the following equation:

Relative quantification of target $=2^{-(\mathrm{Ct} \text { target-Ct total bacteria })}$

Where $\mathrm{Ct}$ represents threshold cycle.

Table 3. PCR primers for real-time PCR assay

\begin{tabular}{|c|c|c|}
\hline Target species & Forward/reverses & Primer sequence \\
\hline \multirow[t]{2}{*}{ Butyrivibrio fibrisolvens $^{1}$} & F & ACCGCATAAGCGCACGGA \\
\hline & $\mathrm{R}$ & CGGGTCCATCTTGTACCGATAAAT \\
\hline \multirow[t]{2}{*}{ Prevotella ruminicoal $^{1}$} & $\mathrm{~F}$ & GCGAAAGTCGGATTAATGCTCTATG \\
\hline & $\mathrm{R}$ & CCCATCCTATAGCGGTAAACCTTTG \\
\hline \multirow[t]{2}{*}{ Sreptococus bovis $^{1}$} & $\mathrm{~F}$ & TTCCTAGAGATAGGAAGTTTCTTCGG \\
\hline & $\mathrm{R}$ & ATGATGGCAACTAACAATAGGGGT \\
\hline \multirow[t]{2}{*}{ Ruminococcus flavefaciens ${ }^{1}$} & $\mathrm{~F}$ & GAGTGAAGTAGAGGTAAGCGGAATTC \\
\hline & $\mathrm{R}$ & GCCGTACTCCCCAGGTGG \\
\hline \multirow[t]{2}{*}{ Ciliate protozoa $^{1}$} & $\mathrm{~F}$ & GCTTTCGWTGGTAGTGTATT \\
\hline & $\mathrm{R}$ & CTTGCCCTCYAATCGTWCT \\
\hline \multirow[t]{2}{*}{ Total bacteria ${ }^{2}$} & $\mathrm{~F}$ & CGGCAACGAGCGCAACCC \\
\hline & $\mathrm{R}$ & CCATTGTAGCACGTGTGTAGCC \\
\hline
\end{tabular}


Data were analyzed as $4 \times 4$ Latin square using Mixed procedure of SAS (version 8.0, 2000). The following model was fitted to all variables that did not have repeated measurements over time.

$$
\mathrm{Y}_{\mathrm{ijkl}}=\mu_{\mathrm{i}}+\mathrm{C}_{\mathrm{i}}+\mathrm{P}_{\mathrm{j}}+\mathrm{T}_{\mathrm{k}}+\mathrm{Z}_{\mathrm{l}}+\varepsilon_{\mathrm{ijkl}}
$$

Where $\mathrm{Y}_{\mathrm{ijkl}}$ is the dependent variable, $\mu$ is the overall mean, $C_{i}$ is the effect of cattle ( $i=1$ to 4 ), $P_{j}$ is the effect of period ( $\mathrm{j}=1$ to 4$), \mathrm{T}_{\mathrm{k}}$ is the effect of treatment ( $\mathrm{k}=1$ to 4 ), $\mathrm{Z}_{\mathrm{l}}$ is the effect of sample time 1 , and $\varepsilon_{\mathrm{ijkl}}$ is the residual error. All terms were considered fixed except for $\varepsilon_{\mathrm{ijkl}}$ which was considered random. Polynomial contrasts were used to assess linear and/or quadratic dose-effects of SSP. Differences among treatments were declared significant at $\mathrm{p}<0.05$ using LSMEANS with PDIFF and adjusted with a Dunnett's test of SAS (2000).

\section{RESULTS}

\section{Ruminal fermentation characteristics}

In general, increasing the rate of SSP infusion from 100 to $300 \mathrm{~g} / \mathrm{d}$ increased concentrations of ammonia-N (L, Q; $\mathrm{p}<0.001)$, MCP $(\mathrm{L}, \mathrm{Q} ; \mathrm{p}<0.001)$ and $\operatorname{VFA}(\mathrm{L} ; \mathrm{p}=0.029)$ and molar proportions of acetate $(\mathrm{Q} ; \mathrm{p}<0.05)$ and propionate $(\mathrm{p}<0.001)$, but reduced molar proportion of butyrate $(\mathrm{L}, \mathrm{p}<0.05 ; \mathrm{Q}, \mathrm{p}<0.001)$ and acetate:propionate (A:P) ratio (L, Q; $\mathrm{p}<0.001$; Table 4). Compared to Control, rumen fluid from all SSP infused cattle had higher $(\mathrm{p}<0.001)$ concentrations of ammonia-N and MCP, lower $(\mathrm{p}<0.001)$ A:P ratio but similar $\mathrm{pH}$. In contrast, effects of
SSP on ruminal VFA profile depended on the rate of SSP infusion. Rumen fluid from cattle in SSP200 and SSP300 had higher $(p<0.05)$ concentrations of VFA and higher $(\mathrm{p}<0.05)$ molar proportions of propionate than that in Control, whereas these differences were not found between SSP100 and Control.

Infusion of SSP at the rates of 100, 200 and $300 \mathrm{~g} / \mathrm{d}$ increased $(\mathrm{p}<0.05)$ percentage of $16 \mathrm{~S} r \mathrm{RNA}$ gene copies of $S$. bovis, but did not affect percentages of $16 \mathrm{~S} r R N A$ gene copies of $P$. ruminicola, $R$. flavefaciens or ciliate protozoa in the total bacterial $16 \mathrm{~S} r \mathrm{RNA}$ gene copies as compared to that of Control. In contrast, percentage of $16 \mathrm{~S} r$ RNA gene copies of $B$. fibrisolvens was increased $(\mathrm{p}<0.05)$ by SSP infused at the rate of $200 \mathrm{~g} / \mathrm{d}$ but not others.

\section{Nutrient intake, flow and digestibility in gastrointestinal tract}

Nutrient intakes and apparent total tract digestibility are presented in Table 5. Because DMI was restrained, intake of DM, OM, NDF, and ADF did not differ among treatments. Nitrogen intake increased as the levels of SSP infusion increasing $(\mathrm{p}<0.05)$. The duodenal flow $(\mathrm{kg} / \mathrm{d})$ of DM was linearly $(\mathrm{p}<0.001)$ and quadratically $(\mathrm{p}<0.001)$ decreased and the duodenal flow of NDF was linearly decreased $(\mathrm{p}=$ 0.042 ) by the infusion of SSP. On the contrary, duodenal flow of ADF increased $(\mathrm{p}<0.05)$ in cattle receiving $300 \mathrm{~g} / \mathrm{d}$ of SSP infusion as compared to the control.

Apparent rumen digestibility of DM was quadratically $(p<0.05)$ increased, and apparent rumen digestibility of NDF was linearly $(p<0.05)$ increased, whereas the ileum flow of NDF decreased (L, Q, p<0.05) with the increasing

Table 4. Effects of soybean small peptide (SSP) infusion into rumen at the rates of 0 (Control), 100 (SSP100), 200 (SSP200) and 300 (SSP300) $\mathrm{g} / \mathrm{d}$ on characteristics of rumen fermentation and microbial abundance as determined by marker gene copy number in total bacterial $16 \mathrm{~S}$ rRNA (percentage of total bacterial $16 \mathrm{~S}$ rRNA) $(\mathrm{n}=4)$

\begin{tabular}{|c|c|c|c|c|c|c|c|}
\hline \multirow{2}{*}{ Item } & \multicolumn{4}{|c|}{ Treatment } & \multirow{2}{*}{ SEM $^{1}$} & \multicolumn{2}{|c|}{ Contrast $^{2}$} \\
\hline & Control & SSP100 & SSP200 & SSP300 & & $\mathrm{L}$ & Q \\
\hline$\overline{\mathrm{pH}}$ & 6.54 & 6.48 & 6.54 & 6.56 & 0.618 & 0.686 & 0.820 \\
\hline Ammonia N (mg/L) & $66.91^{\mathrm{c}}$ & $84.39^{\mathrm{b}}$ & $96.79^{\mathrm{b}}$ & $116.31^{\mathrm{a}}$ & 9.363 & $<0.001$ & $<0.001$ \\
\hline Microbial protein $(\mathrm{mg} / \mathrm{L})$ & $62.49^{c}$ & $74.99^{\mathrm{b}}$ & $82.27^{\mathrm{b}}$ & $92.45^{\mathrm{a}}$ & 8.594 & $<0.001$ & $<0.001$ \\
\hline Total VFA (mmol/L) & $86.03^{\mathrm{b}}$ & $89.92^{\mathrm{ab}}$ & $91.74^{\mathrm{a}}$ & $92.01^{\mathrm{a}}$ & 1.313 & 0.029 & 0.092 \\
\hline Acetate $(\mathrm{mol} / 100 \mathrm{~mol})$ & $75.97^{\mathrm{a}}$ & $71.93^{\mathrm{c}}$ & $73.74^{\mathrm{bc}}$ & $74.35^{\mathrm{ab}}$ & 1.035 & 0.423 & 0.038 \\
\hline Propionate $(\mathrm{mol} / 100 \mathrm{~mol})$ & $13.98^{\mathrm{c}}$ & $14.53^{\mathrm{c}}$ & $16.48^{\mathrm{b}}$ & $19.14^{\mathrm{a}}$ & 0.8 & $<0.001$ & $<0.001$ \\
\hline Butyrate (mol/100mol) & $10.05^{\mathrm{b}}$ & $13.55^{\mathrm{a}}$ & $9.78^{\mathrm{b}}$ & $6.51^{\mathrm{c}}$ & 1.004 & 0.022 & $<0.001$ \\
\hline Acetate:propionate & $5.45^{\mathrm{a}}$ & $4.95^{\mathrm{b}}$ & $4.49^{c}$ & $3.92^{\mathrm{d}}$ & 0.672 & $<0.001$ & $<0.001$ \\
\hline \multicolumn{8}{|l|}{ Ruminal microbial } \\
\hline P. ruminicola $\left(\times 10^{-2}\right)$ & 1.94 & 2.18 & 2.03 & 2.21 & 0.732 & 0.231 & 0.437 \\
\hline R. flavefaciens $\left(\times 10^{-2}\right)$ & 5.51 & 5.91 & 5.78 & 5.75 & 0.832 & 0.699 & 0.93 \\
\hline B. fibrisolvens $\left(\times 10^{-4}\right)$ & $1.50^{\mathrm{b}}$ & $1.68^{\mathrm{ab}}$ & $1.82^{\mathrm{a}}$ & $1.70^{\mathrm{ab}}$ & 0.622 & 0.162 & 0.194 \\
\hline S. bovis $\left(\times 10^{-6}\right)$ & $5.91^{\mathrm{a}}$ & $4.87^{\mathrm{b}}$ & $4.85^{\mathrm{b}}$ & $4.94^{\mathrm{b}}$ & 0.801 & 0.049 & 0.020 \\
\hline Ciliate protozoa $\left(\times 10^{-2}\right)$ & 3.82 & 3.83 & 3.98 & 3.87 & 0.771 & 0.686 & 0.866 \\
\hline
\end{tabular}

${ }^{1} \mathrm{SEM}=$ Standard error of mean. ${ }^{2} \mathrm{p}$ values for the linear $(\mathrm{L})$ or quadratic $(\mathrm{Q})$ effects of SSP infused at the rates $0,100,200,300 \mathrm{~g} \cdot \mathrm{cattle}^{-1} \cdot \mathrm{d}^{-1}$.

${ }^{\mathrm{a}-\mathrm{d}}$ Means within a row with different superscript letter differ $(\mathrm{p}<0.05)$. 
Table 5. Effects of soybean small peptide (SSP) infusion into rumen at the rates of 0 (Control), 100 (SSP100), 200 (SSP200) and 300 (SSP300) g/d on digestion of nutrient at different digestive sites of Luxi Yellow cattle $(n=4)$

\begin{tabular}{|c|c|c|c|c|c|c|c|}
\hline \multirow{2}{*}{ Item } & \multicolumn{4}{|c|}{ Treatment } & \multirow{2}{*}{$\mathrm{SEM}^{1}$} & \multicolumn{2}{|c|}{ Contrast $^{2}$} \\
\hline & Control & SSP100 & SSP200 & SSP300 & & $\mathrm{L}$ & $\mathrm{Q}$ \\
\hline \multicolumn{8}{|l|}{$\overline{\mathrm{DM}}$} \\
\hline Flux to duodenum $(\mathrm{kg} / \mathrm{d})$ & $4.15^{\mathrm{a}}$ & $4.15^{\mathrm{a}}$ & $4.07^{\mathrm{a}}$ & $3.97^{\mathrm{b}}$ & 2.675 & $<0.001$ & $<0.001$ \\
\hline Flux to ileum $(\mathrm{kg} / \mathrm{d})$ & 3.21 & 3.18 & 3.15 & 3.14 & 3.227 & 0.381 & 0.677 \\
\hline Fecal flux $(\mathrm{kg} / \mathrm{d})$ & $2.71^{\mathrm{a}}$ & $2.62^{\mathrm{b}}$ & $2.59^{\mathrm{bc}}$ & $2.53^{\mathrm{c}}$ & 2.569 & 0.001 & 0.002 \\
\hline \multicolumn{8}{|c|}{ Apparent digestion, of intake $(\mathrm{g} / 100 \mathrm{~g})$} \\
\hline Rumen & $43.02^{\mathrm{b}}$ & $43.14^{\mathrm{b}}$ & $44.12^{\mathrm{b}}$ & $45.49^{\mathrm{a}}$ & 0.918 & 0.067 & 0.021 \\
\hline Small intestine & 12.92 & 13.48 & 12.63 & 11.4 & 1.092 & 0.184 & 0.275 \\
\hline Large intestine & 6.94 & 7.79 & 7.65 & 8.39 & 1.055 & 0.189 & 0.436 \\
\hline Total tract & $62.88^{\mathrm{b}}$ & $64.41^{\mathrm{a}}$ & $64.40^{\mathrm{a}}$ & $65.28^{\mathrm{a}}$ & 0.905 & $<0.001$ & 0.002 \\
\hline \multicolumn{8}{|l|}{$\mathrm{OM}$} \\
\hline Flux to duodenum $(\mathrm{kg} / \mathrm{d})$ & $3.93^{\mathrm{a}}$ & $3.97^{\mathrm{a}}$ & $3.91^{\mathrm{a}}$ & $3.80^{\mathrm{b}}$ & 2.373 & 0.123 & 0.153 \\
\hline Flux to ileum $(\mathrm{kg} / \mathrm{d})$ & 3.05 & 3 & 2.97 & 2.96 & 3.319 & 0.183 & 0.399 \\
\hline Fecal flux $(\mathrm{kg} / \mathrm{d})$ & $2.61^{\mathrm{a}}$ & $2.47^{\mathrm{b}}$ & $2.47^{\mathrm{b}}$ & $2.42^{\mathrm{b}}$ & 2.774 & $<0.001$ & 0.001 \\
\hline \multicolumn{8}{|c|}{ Apparent digestion, of intake $(\mathrm{g} / 100 \mathrm{~g})$} \\
\hline Rumen & $47.54^{\mathrm{b}}$ & $47.04^{\mathrm{b}}$ & $47.80^{\mathrm{b}}$ & $49.26^{\mathrm{a}}$ & 0.807 & 0.981 & 0.25 \\
\hline Small intestine & 11.77 & 12.83 & 12.64 & 11.23 & 1.15 & 0.713 & 0.484 \\
\hline Large intestine & 5.83 & 7.13 & 6.62 & 7.29 & 1.072 & $<0.001$ & 0.001 \\
\hline Total tract & $65.13^{\mathrm{b}}$ & $67.00^{\mathrm{a}}$ & $67.05^{\mathrm{a}}$ & $67.79^{\mathrm{a}}$ & 0.943 & $<0.001$ & 0.001 \\
\hline \multicolumn{8}{|l|}{$\mathrm{NDF}$} \\
\hline Flux to duodenum $(\mathrm{kg} / \mathrm{d})$ & $2.17^{\mathrm{a}}$ & $2.11^{\mathrm{ab}}$ & $2.15^{\mathrm{ab}}$ & $2.09^{\mathrm{b}}$ & 2.532 & 0.042 & 0.136 \\
\hline Flux to ileum $(\mathrm{kg} / \mathrm{d})$ & $2.08^{\mathrm{a}}$ & $1.98^{\mathrm{ab}}$ & $1.99^{\mathrm{ab}}$ & $1.94^{\mathrm{b}}$ & 2.848 & 0.022 & 0.04 \\
\hline Fecal flux (kg/d) & $1.73^{\mathrm{a}}$ & $1.71^{\mathrm{a}}$ & $1.66^{\mathrm{b}}$ & $1.61^{\mathrm{c}}$ & 2.224 & 0.001 & 0.004 \\
\hline \multicolumn{8}{|c|}{ Apparent digestion, of intake $(\mathrm{g} / 100 \mathrm{~g})$} \\
\hline Rumen & 48.77 & 50.28 & 49.26 & 50.81 & 0.992 & 0.042 & 0.136 \\
\hline Small intestine & 2.22 & 2.91 & 3.85 & 3.42 & 1.13 & 0.177 & 0.31 \\
\hline Large intestine & 8.27 & 6.22 & 7.76 & 7.68 & 1.106 & 0.951 & 0.582 \\
\hline Total tract & $59.26^{\mathrm{c}}$ & $59.42^{\mathrm{c}}$ & $60.87^{\mathrm{b}}$ & $61.91^{\mathrm{a}}$ & 0.863 & 0.001 & 0.004 \\
\hline \multicolumn{8}{|l|}{$\mathrm{ADF}$} \\
\hline Flux to duodenum (kg/d) & $1.32^{\mathrm{b}}$ & $1.34^{\mathrm{ab}}$ & $1.34^{\mathrm{ab}}$ & $1.38^{\mathrm{a}}$ & 2.328 & 0.068 & 0.183 \\
\hline Flux to ileum $(\mathrm{kg} / \mathrm{d})$ & 1.26 & 1.24 & 1.22 & 1.26 & 2.627 & 0.95 & 0.66 \\
\hline Fecal flux (kg/d) & 1.09 & 1.05 & 1.04 & 1.05 & 2.366 & 0.122 & 0.084 \\
\hline \multicolumn{8}{|c|}{ Apparent digestion, of intake $(\mathrm{g} / 100 \mathrm{~g})$} \\
\hline Rumen & $34.80^{\mathrm{a}}$ & $33.70^{\mathrm{ab}}$ & $33.84^{\mathrm{ab}}$ & $31.84^{\mathrm{b}}$ & 1.098 & 0.068 & 0.183 \\
\hline Small intestine & 3.07 & 4.84 & 5.55 & 5.61 & 1.246 & 0.068 & 0.137 \\
\hline Large intestine & 8.13 & 9.52 & 9.13 & 10.44 & 1.161 & 0.145 & 0.36 \\
\hline Total tract & 45.99 & 48.06 & 48.53 & 47.90 & 1.116 & 0.122 & 0.085 \\
\hline \multicolumn{8}{|l|}{$\mathrm{N}$} \\
\hline Intake $(\mathrm{g} / \mathrm{d})$ & $119.1^{\mathrm{d}}$ & $130.4^{\mathrm{c}}$ & $142.1^{\mathrm{a}}$ & $153.2^{\mathrm{b}}$ & 0.71 & $<0.001$ & $<0.001$ \\
\hline Flux to duodenum (g/d) & 121.7 & 125.0 & 129.6 & 132.9 & 1.71 & 0.019 & 0.072 \\
\hline Flux to ileum (g/d) & 51.84 & 53.31 & 58.29 & 62.3 & 1.611 & 0.008 & 0.032 \\
\hline Fecal flux (g/d) & 48.07 & 47.18 & 48.91 & 49.39 & 1.152 & 0.406 & 0.649 \\
\hline Urinary $(\mathrm{g} / \mathrm{d})$ & $52.41^{\mathrm{a}}$ & $57.65^{\mathrm{b}}$ & $55.37^{\mathrm{c}}$ & $63.94^{\mathrm{d}}$ & 0.908 & $<0.001$ & $<0.001$ \\
\hline Retain nitrogen $(\mathrm{g} / \mathrm{d})$ & $18.65^{\mathrm{c}}$ & $25.54^{\mathrm{b}}$ & $37.77^{\mathrm{a}}$ & $39.83^{\mathrm{a}}$ & 1.057 & $<0.001$ & $<0.001$ \\
\hline
\end{tabular}

${ }^{1} \mathrm{SEM}=$ Standard error of mean. ${ }^{2} \mathrm{p}$ values for the linear (L) or quadratic (Q) effects of SSP infused at the rates $0,100,200,300 \mathrm{~g} \cdot \mathrm{cattle}^{-1} \cdot \mathrm{d}^{-1}$.

${ }^{\mathrm{a}-\mathrm{d}}$ Means within a row with different superscript letter differ $(\mathrm{p}<0.05)$.

rate of SSP infusion. Similarly, OM digestion in the large intestine and the total tract digestion of DM, OM, and NDF were also linearly and quadratically $(p<0.01)$ increased as the rate of SSP infusion increased.

Ruminal infusion of SSP at the rates up to $300 \mathrm{~g} / \mathrm{d}$ did not affect $\mathrm{N}$ flow to duodenum and ileum or fecal $\mathrm{N}$ output, but increased urinary $\mathrm{N}$ excretion $(\mathrm{L}, \mathrm{Q} ; \mathrm{p}<0.001)$ and $\mathrm{N}$ retention $(\mathrm{L}, \mathrm{Q} ; \mathrm{p}<0.001)$.

\section{Flux and digestion of AA at different digestive sites}

Ruminal infusion of SSP increased $(\mathrm{p}<0.05)$ duodenal flux of all 17 AA examined in this study as compared to 
Table 6. Effects of soybean small peptide (SSP) infusion into rumen at the rates of 0 (Control), 100 (SSP100), 200 (SSP200) and 300 (SSP300) g/d on flux of amino acids at proximate duodenum of Luxi Yelow cattle $(n=4)$

\begin{tabular}{|c|c|c|c|c|c|c|c|}
\hline \multirow{2}{*}{ Item } & \multicolumn{4}{|c|}{ Treatment } & \multirow{2}{*}{ SEM $^{1}$} & \multicolumn{2}{|c|}{ Contrast $^{2}$} \\
\hline & Control & SSP100 & SSP200 & SSP300 & & $\mathrm{L}$ & Q \\
\hline Aspartic acid & $43.20^{\mathrm{b}}$ & $45.59^{\mathrm{b}}$ & $54.87^{\mathrm{a}}$ & $57.74^{\mathrm{a}}$ & 1.308 & $<0.001$ & $<0.001$ \\
\hline Glutamic acid & $72.26^{\mathrm{c}}$ & $78.00^{\mathrm{b}}$ & $89.87^{\mathrm{a}}$ & $94.24^{\mathrm{a}}$ & 1.330 & $<0.001$ & $<0.001$ \\
\hline Serine & $29.67^{\mathrm{c}}$ & $31.73^{\mathrm{c}}$ & $40.66^{\mathrm{b}}$ & $44.46^{\mathrm{a}}$ & 1.106 & $<0.001$ & $<0.001$ \\
\hline Glycine & $23.26^{\mathrm{bc}}$ & $22.10^{c}$ & $26.78^{\mathrm{b}}$ & $31.57^{\mathrm{a}}$ & 1.240 & $<0.001$ & $<0.001$ \\
\hline Histidine & $13.86^{\mathrm{c}}$ & $17.42^{\mathrm{b}}$ & $18.21^{\mathrm{ab}}$ & $19.71^{\mathrm{a}}$ & 0.968 & $<0.001$ & $<0.001$ \\
\hline Arginine & $23.01^{\mathrm{c}}$ & $24.95^{\mathrm{b}}$ & $27.96^{\mathrm{a}}$ & $28.49^{\mathrm{a}}$ & 1.010 & $<0.001$ & 0.002 \\
\hline Threonine & $25.04^{\mathrm{c}}$ & $26.62^{\mathrm{bc}}$ & $29.36^{\mathrm{ab}}$ & $30.95^{\mathrm{a}}$ & 1.130 & $<0.001$ & $<0.001$ \\
\hline Alanine & $30.10^{\mathrm{b}}$ & $30.14^{\mathrm{b}}$ & $29.76^{\mathrm{b}}$ & $36.73^{\mathrm{a}}$ & 0.922 & 0.004 & $<0.001$ \\
\hline Proline & $27.79^{\mathrm{c}}$ & $31.43^{\mathrm{b}}$ & $33.97^{\mathrm{b}}$ & $38.12^{\mathrm{a}}$ & 1.127 & $<0.001$ & $<0.001$ \\
\hline Tyrosine & $17.80^{\mathrm{ab}}$ & $15.87^{\mathrm{c}}$ & $16.86^{\mathrm{bc}}$ & $19.21^{\mathrm{a}}$ & 0.979 & 0.161 & 0.003 \\
\hline Valine & $30.74^{\mathrm{c}}$ & $31.96^{\mathrm{bc}}$ & $33.39^{\mathrm{ba}}$ & $34.38^{\mathrm{a}}$ & 1.053 & $<0.001$ & 0.002 \\
\hline Methionine & $8.66^{\mathrm{b}}$ & $9.68^{\mathrm{ba}}$ & $10.54^{\mathrm{ba}}$ & $10.82^{\mathrm{a}}$ & 1.019 & 0.003 & 0.009 \\
\hline Cystine & $8.96^{\mathrm{c}}$ & $8.97^{\mathrm{c}}$ & $10.17^{\mathrm{b}}$ & $12.32^{\mathrm{a}}$ & 0.849 & $<0.001$ & $<0.001$ \\
\hline Isoleucine & $26.37^{\mathrm{b}}$ & $28.36^{\mathrm{ab}}$ & $30.27^{\mathrm{a}}$ & $30.31^{\mathrm{a}}$ & 1.154 & 0.004 & 0.009 \\
\hline Leucine & $42.02^{\mathrm{b}}$ & $44.74^{\mathrm{b}}$ & $49.06^{\mathrm{a}}$ & $49.93^{\mathrm{a}}$ & 1.232 & $<0.001$ & $<0.001$ \\
\hline Phenylalanine & $20.59^{c}$ & $23.39^{\mathrm{b}}$ & $26.30^{\mathrm{a}}$ & $25.07^{\mathrm{a}}$ & 0.964 & 0.002 & $<0.001$ \\
\hline Lysine & $25.38^{\mathrm{d}}$ & $29.88^{c}$ & $33.50^{\mathrm{b}}$ & $35.78^{\mathrm{a}}$ & 1.067 & $<0.001$ & $<0.001$ \\
\hline $\mathrm{TAA}^{3}$ & $468.43^{b}$ & $495.15^{b}$ & $548.73^{\mathrm{a}}$ & $583.85^{\mathrm{a}}$ & 2.181 & $<0.001$ & $<0.001$ \\
\hline NEAA $^{4}$ & $244.08^{d}$ & $254.85^{\mathrm{c}}$ & $292.75^{\mathrm{b}}$ & $322.07^{\mathrm{a}}$ & 1.509 & $<0.001$ & $<0.001$ \\
\hline EAA $^{5}$ & $224.63^{c}$ & $245.97^{b}$ & $269.62^{\mathrm{a}}$ & $276.85^{\mathrm{a}}$ & 1.604 & $<0.001$ & $<0.001$ \\
\hline
\end{tabular}

${ }^{1}$ SEM $=$ Standard error of mean. ${ }^{2} \mathrm{p}$ values for the linear (L) or quadratic (Q) effects of SSP infused at the rates 0, 100, 200, 300 g.cattle ${ }^{-1} \cdot \mathrm{d}^{-1}$.

${ }^{3} \mathrm{TAA}=$ Total amino acids. ${ }^{4}$ NEAA $=$ Non-essential amino acids. ${ }^{5}$ EAA $=$ Essential amino acids.

${ }^{a-d}$ Means within a row with different superscript letter differ $(\mathrm{p}<0.05)$.

Control (Table 6). The efficacy of different amounts of SSP on the AA duodenal flux depended on the individual AA with the greatest effects observed at the higher dosage. In general, increasing the amount of infused SSP from 100 to $300 \mathrm{~g} / \mathrm{d}$ linearly and quadratically increased $(\mathrm{p}<0.01)$ increased duodenal flux of 17 AA with the exception of Tyrosine that was only quadratically $(p<0.01)$ increased by the infusion of SSP. Similarly, flux at the terminal ileum of AA examined were also increased $(\mathrm{p}<0.05)$ by the ruminal infusion of SSP compared to Control with the exception of Arginine, Threonine, Tyrosine, and Methionine (Table 7). The increased flux of these AA by SSP was also observed in a dose dependent manner and most of them were linearly and/or quadratically $(\mathrm{p}<0.05)$ increased as the SSP increased from 100 to $300 \mathrm{~g} / \mathrm{d}$. In contrast, the digestibilities of most of the AA examined in the small intestine were not affected by SSP (Table 8) and increased AA digestibility was only observed for Arginine at SSP100, SSP200 and SSP300 and for Lysine at SSP200 ( $<<0.05)$.

\section{DISCUSSION}

\section{Effect of ruminal SSP infusion on rumen fermentation}

In the current study, infusion SSP into the rumen had no effect on ruminal $\mathrm{pH}$, which is consistent with other reports using peptides or sodium caseinate (Cruz Soto et al., 1994;
Kazemi et al., 2010). However, ammonia-N was linearly increased as the SSP infusion rate increased, indicating a portion of the infused SSP was degraded and deaminated to ammonia. Increasing crude protein concentration or degradation of dietary protein usually results in increased ammonia concentrations in the rumen (Davidson et al., 2003). Increased ammonia concentration in the rumen was also observed when casein was infused into rumen (Khalili and Huhanen, 2002; Kazemi et al., 2010). Microbial protein synthesized in the rumen is influenced by many factors such as fermentative synchrony of degradable carbohydrate and ruminally degradable protein, ammonia concentration and $\mathrm{pH}$ (Fu et al, 2001) and it has been reported that between 18 and $100 \%$ microbial protein was derived from ammonia-N Salter et al. (1979). Providing peptides has been shown to stimulate the growth of rumen bacteria (Cruz Soto et al., 1994; Chikunya et al., 1996), and to enhance digestion of fiber (McAllan, 1991; Griswold et al., 1996). The results of this study demonstrated that infusion of SSP in the rumen positively increased microbial crude protein synthesis, which is consistent with another report that showed that supplying peptides and free amino acid to the rumen stimulated microbial yield and fermentation (Chikunya et al., 1996). The enhanced MCP synthesis by SSP infusion may partly due to the increased availability of ammonia-N and the improved synchronization between fermentative 
Table 7. Effects of soybean small peptide (SSP) infusion into rumen at the rates of 0 (Control), 100 (SSP100), 200 (SSP200) and 300 (SSP300) g/d on flux of amino acids at the terminal ilenum of Luxi Yelow cattle $(\mathrm{n}=4)$

\begin{tabular}{|c|c|c|c|c|c|c|c|}
\hline \multirow{2}{*}{ Item } & \multicolumn{4}{|c|}{ Treatment } & \multirow{2}{*}{ SEM $^{1}$} & \multicolumn{2}{|c|}{ Contrast $^{2}$} \\
\hline & Control & SSP100 & SSP200 & SSP300 & & $\mathrm{L}$ & $\mathrm{Q}$ \\
\hline Aspartic acid & $13.76^{\mathrm{b}}$ & $14.49^{\mathrm{b}}$ & $17.89^{\mathrm{a}}$ & $18.87^{\mathrm{a}}$ & 1.015 & $<0.001$ & 0.005 \\
\hline Glutamic acid & $25.26^{\mathrm{b}}$ & $26.91^{\mathrm{ab}}$ & $31.29^{\mathrm{ab}}$ & $32.57^{\mathrm{a}}$ & 1.393 & 0.004 & 0.018 \\
\hline Serine & $12.22^{\mathrm{c}}$ & $12.80^{\mathrm{c}}$ & $15.19^{\mathrm{b}}$ & $17.80^{\mathrm{a}}$ & 0.946 & $<0.001$ & 0.002 \\
\hline Glycine & $9.65^{\mathrm{b}}$ & $9.02^{\mathrm{b}}$ & $10.69^{\mathrm{ab}}$ & $12.47^{\mathrm{a}}$ & 1.034 & 0.001 & $<0.001$ \\
\hline Histidine & $3.10^{\mathrm{b}}$ & $4.06^{\mathrm{a}}$ & $4.57^{\mathrm{a}}$ & $4.53^{\mathrm{a}}$ & 0.790 & $<0.001$ & $<0.001$ \\
\hline Arginine & 6.74 & 6.46 & 6.28 & 6.93 & 0.856 & 0.780 & 0.328 \\
\hline Threonine & 9.325 & 9.325 & 9.88 & 10.77 & 1.005 & 0.049 & 0.123 \\
\hline Alanine & $10.37^{\mathrm{b}}$ & $10.18^{\mathrm{b}}$ & $10.78^{\mathrm{ab}}$ & $13.16^{\mathrm{a}}$ & 1.099 & 0.020 & 0.018 \\
\hline Proline & $12.13^{\mathrm{b}}$ & $13.33^{\mathrm{b}}$ & $14.09^{\mathrm{ab}}$ & $16.27^{\mathrm{a}}$ & 1.125 & $<0.001$ & 0.001 \\
\hline Tyrosine & $6.30^{\mathrm{b}}$ & $5.62^{\mathrm{b}}$ & $6.02^{\mathrm{b}}$ & $7.20^{\mathrm{a}}$ & 0.807 & 0.340 & 0.268 \\
\hline Valine & 10.18 & 10.74 & 11.40 & 12.05 & 1.008 & 0.007 & 0.031 \\
\hline Methionine & 2.4 & 2.38 & 2.58 & 2.75 & 0.786 & 0.107 & 0.242 \\
\hline Cystine & $2.96^{\mathrm{b}}$ & $2.91^{\mathrm{b}}$ & $2.76^{\mathrm{b}}$ & $3.86^{\mathrm{a}}$ & 0.836 & 0.062 & 0.017 \\
\hline Isoleucine & 6.83 & 7.45 & 7.74 & 8.49 & 0.990 & 0.018 & 0.067 \\
\hline Leucine & $11.79^{\mathrm{c}}$ & $12.38^{\mathrm{bc}}$ & $13.13^{\mathrm{ab}}$ & $14.34^{\mathrm{a}}$ & 0.922 & $<0.001$ & 0.004 \\
\hline Phenylalanine & $6.68^{c}$ & $7.18^{\mathrm{bc}}$ & $7.82^{\mathrm{ab}}$ & $8.64^{\mathrm{a}}$ & 0.853 & $<0.001$ & 0.001 \\
\hline Lysine & $6.43^{\mathrm{b}}$ & $6.83^{\mathrm{ab}}$ & $7.07^{\mathrm{ab}}$ & $8.04^{\mathrm{a}}$ & 0.915 & 0.002 & 0.007 \\
\hline $\mathrm{TAA}^{3}$ & $158.04^{\mathrm{c}}$ & $162.25^{\mathrm{bc}}$ & $179.13^{\mathrm{b}}$ & $198.73^{a}$ & 1.787 & $<0.001$ & 0.001 \\
\hline NEAA $^{4}$ & $89.68^{\mathrm{b}}$ & $92.35^{\mathrm{b}}$ & $105.93^{\mathrm{a}}$ & $118.33^{\mathrm{a}}$ & 1.658 & $<0.001$ & $<0.001$ \\
\hline EAA $^{5}$ & $66.43^{\mathrm{c}}$ & $69.91^{\mathrm{bc}}$ & $73.20^{\mathrm{b}}$ & $80.40^{\mathrm{a}}$ & 1.334 & $<0.001$ & $<0.001$ \\
\hline
\end{tabular}

${ }^{1}$ SEM $=$ Standard error of mean. ${ }^{2} \mathrm{p}$ values for the linear (L) or quadratic (Q) effects of SSP infused at the rates $0,100,200,300 \mathrm{~g} \cdot$ cattle $^{-1} \cdot \mathrm{d}^{-1}$.

${ }^{3} \mathrm{TAA}=$ Total amino acids. ${ }^{4}$ NEAA $=$ Non-essential amino acids. ${ }^{5} \mathrm{EAA}=$ Essential amino acids.

${ }^{\mathrm{a}-\mathrm{c}}$ Means within a row with different superscript letter differ $(\mathrm{p}<0.05)$.

Table 8. Effects of soybean small peptide (SSP) infusion into rumen at the rates of 0 (Control), 100 (SSP100), 200 (SSP200) and 300 (SSP300) g/d on digestion ( $\mathrm{g} / \mathrm{g}$ ) of amino acids in the small intestine of Luxi Yelow cattle $(\mathrm{n}=4)$

\begin{tabular}{|c|c|c|c|c|c|c|c|}
\hline \multirow{2}{*}{ Item } & \multicolumn{4}{|c|}{ Treatment } & \multirow{2}{*}{ SEM $^{1}$} & \multicolumn{2}{|c|}{ Contrast $^{2}$} \\
\hline & Control & SSP100 & SSP200 & SSP300 & & $\mathrm{L}$ & $\mathrm{Q}$ \\
\hline Aspartic acid & 68.00 & 68.25 & 68.34 & 67.22 & 1.285 & 0.811 & 0.924 \\
\hline Glutamic acid & 64.94 & 65.52 & 62.21 & 65.35 & 1.470 & 0.843 & 0.930 \\
\hline Serine & 58.89 & 59.66 & 60.58 & 59.83 & 1.316 & 0.675 & 0.857 \\
\hline Glycine & 59.35 & 59.11 & 61.76 & 60.17 & 1.531 & 0.419 & 0.638 \\
\hline Histidine & 77.46 & 76.61 & 76.55 & 76.93 & 1.331 & 0.827 & 0.916 \\
\hline Arginine & $70.71^{\mathrm{b}}$ & $70.01^{\mathrm{a}}$ & $76.74^{\mathrm{a}}$ & $75.54^{\mathrm{a}}$ & 1.117 & 0.032 & 0.042 \\
\hline Threonine & 62.74 & 64.20 & 64.63 & 65.18 & 1.425 & 0.300 & 0.575 \\
\hline Alanine & 65.44 & 66.16 & 65.06 & 64.18 & 1.413 & 0.633 & 0.845 \\
\hline Proline & 56.34 & 27.48 & 58.28 & 57.35 & 1.540 & 0.681 & 0.816 \\
\hline Tyrosine & 64.28 & 64.43 & 65.82 & 61.99 & 1.409 & 0.784 & 0.876 \\
\hline Valine & 66.79 & 66.34 & 65.03 & 64.97 & 1.416 & 0.325 & 0.622 \\
\hline Methionine & 72.31 & 75.06 & 76.54 & 74.61 & 1.437 & 0.332 & 0.291 \\
\hline Cystine & 66.87 & 67.76 & 68.61 & 73.22 & 1.509 & 0.311 & 0.299 \\
\hline Isoleucine & 74.04 & 73.69 & 74.85 & 71.94 & 1.463 & 0.561 & 0.692 \\
\hline Leucine & 71.86 & 72.25 & 72.78 & 70.64 & 1.328 & 0.625 & 0.603 \\
\hline Phenylalanine & $67.56^{\mathrm{ab}}$ & $69.24^{\mathrm{ab}}$ & $70.23^{\mathrm{a}}$ & $65.48^{\mathrm{b}}$ & 1.212 & 0.510 & 0.131 \\
\hline Lysine & $74.63^{\mathrm{b}}$ & $77.10^{\mathrm{ab}}$ & $79.35^{\mathrm{a}}$ & $77.52^{\mathrm{ab}}$ & 1.232 & 0.060 & 0.033 \\
\hline $\mathrm{TAA}^{3}$ & 66.25 & 67.12 & 67.46 & 65.81 & 1.228 & 0.887 & 0.711 \\
\hline NEAA $^{4}$ & 63.23 & 63.77 & 63.79 & 63.23 & 1.312 & 0.998 & 0.948 \\
\hline EAA $^{5}$ & 70.42 & 71.54 & 72.83 & 70.95 & 1.164 & 0.458 & 0.149 \\
\hline
\end{tabular}

${ }^{1}$ SEM $=$ Standard error of mean. ${ }^{2} \mathrm{p}$ values for the linear (L) or quadratic (Q) effects of SSP infused at the rates $0,100,200,300 \mathrm{~g} \cdot \mathrm{cattle}^{-1} \cdot \mathrm{d}^{-1}$.

${ }^{3} \mathrm{TAA}=$ Total amino acids. ${ }^{4}$ NEAA $=$ Non-essential amino acids. ${ }^{5}$ EAA $=$ Essential amino acids.

${ }^{a-b}$ Means within a row with different superscript letter differ $(p<0.05)$. 
energy and ammonia-N (Cruz Soto et al., 1994; Chikunya et al., 1996).

In the present study, rumen concentration of total VFA and molar proportions of propionate were increased but molar proportion of butyrate and acetate: propionate ration were reduced by SSP infusion. This indicated that SSP infusion increased energy supply to the animal as well as improved energy efficiency. Griswold et al. (1996) found total VFA, acetate and butyrate were all increased by adding different amounts and sources of rumen degradable protein. However, Hristov et al. (2004) reported no effect of different rumen degradable protein levels on concentrations of total VFA, acetate, butyrate or propionate in rumen fluid. The discrepancy in the effects of the various forms of rumen degradable proteins on the rumen VFA profile among these studies might be due to the differences in type of animals, diet and the sources of rumen degradable proteins.

\section{Effect of SSP infusion on ruminal microbial communities}

This study found that infusion of SSP had no effect on the population of $R$. flavefaciens, increased the population of B. Fibrisolvens but reduced population of $S$. bovis. It has been shown that some hemicelluloytic bacteria (e.g., $B$. fibrisolvens) utilize peptide or AA N directly for microbial protein synthesis (Cotta and Hespell, 1986). F.succinogenes, $R$. flavefaciens and $R$. albus are the main cellulolytic bacteria in the rumen (Forsberg et al., 1997) and all of them utilize ammonia-N. The results of this study may suggest that effect of ruminal infusion of SSP on rumen bacteria depend on bacterial capability in utilizing peptide- AA- and ammonia-N.

\section{Effect of SSP infusion on nutrient digestibility}

It is generally regarded that ruminally available $\mathrm{N}$ in the form of peptides and AA can improve the digestion of both structural carbohydrate and nonstructural carbohydrate by rumen microorganisms. However, the Cornell net carbohydrate and protein system assumes that bacteria fermenting structural carbohydrates do not utilize peptides or amino acid and all their $\mathrm{N}$ must come from $\mathrm{NH}_{3}$ (Russell et al., 1992). The improved ruminal digestion of NDF by SSP infusion observed in this study indicated that microbial activity relating to fibre digestion was enhanced by the SSP infusion and this is consistent with the finding of increased microbial protein concentration by infusion of SSP in this study. The digestibility of crude fiber was also increased by addition of SSP in the diet of the goats (Zhang et al., 2004). The exact mechanism by which the microbial activity was increased by supply of SSP is not clear. However, the result that the linear increase of microbial protein was positively associated with the linear increase of ruminal ammonia-N by SSP infusion suggests that increasing the rate of SSP infusion increased the production of ammonia- $\mathrm{N}$ thereby enhanced MCP synthesis. Bryant (1973) proposed that ammonia-N in rumen fluid could stimulate the activity of cellulolytic bacteria. On the other hand, Carro and Miller (1999) argued that $\mathrm{N}$ forms other than $\mathrm{NH}_{3}-\mathrm{N}$ are needed for both maximum growth of fiber digesting ruminal microorganisms for maximum fiber digestion. Therefore the increased MCP by SSP infusion might be a combined result of increased ammonia-N and NAN.

Overall, the results of this study showed ruminal infusion of SSP at the rates of 100, 200 and $300 \mathrm{~g} / \mathrm{d}$ increased the apparent digestibilities of DM, OM, NDF and $\mathrm{CP}$ in the total digestive tract of beef cattle. The fact that the improvement in digestibilities of the nutrient by SSP mainly occurred in the rumen indicated that the beneficial effects of supplying SSP on nutrient digestion were mainly through improving rumen fermentation efficiency.

\section{Effect of infusion SSP on AA flow and apparent digestibility of small intestinal}

Ruminal infusion of SSP increased all measured AA flux to the small intestine without affecting their digestibility in the small intestine. This suggests that amount of AA absorbed from the small intestine was increased, which is consistent with the observation of an increased amount of $\mathrm{N}$ retained due to SSP infusion. The increased AA flux to the small intestine by SPP infusion is likely a combined result of increased flux of ruminal undegradable SPP and MCP. The similar small intestinal digestibility of AA across all the treatments also indicate that the small intestinal digestibility of AA in SPP is similar to that of other feed components used in this study.

\section{IMPLICATIONS}

In this experiment, infusion soybean small peptide profoundly influenced ruminal fermentation, duodenal and ileal amino acid flow, and digestion of dry matter, organic matter and fiber. Soybean small peptide may improve the absorption of individual amino acids in the small intestine. But there are still many questions to be answered, including the ruminal degradability of small peptides, the net absorption of intact peptides in the gastrointestinal tract and the influence on microbial population of infusion soybean small peptides, specially the relationship between peptide nitrogen and fiber. More research is needed in this area to determine the intake at which undegraded intake soybean small peptide supplementation becomes beneficial. Although practical application of peptides to livestock nutrition is lacking, further investigations will provide more 
information, which may enable the improvement of nutritional management decisions.

\section{REFERENCES}

Adibi, S. A., H. Lochs, N. N. Abumrad, H. Daniel and J. A. Vazquez. 1993. Removal of glycylglutamine from plasma by individual tissues: mechanism and impact on amino acid fluxes in postabsorption and starvation. J. Nutr. 123:325-331.

Andries, J. I., F. X. Buysse, D. L. De Brabander and B. G. Cottyn. 1987. Isoacids in ruminant nutrition: their role in ruminal and intermediary metabolism and possible influences on performances-a review. Anim. Feed. Sci. Technol. 18:169-180.

AOAC. 1997. Official methods of analysis. 16th edn. Association of Official Analytical Chemists, Arlington, Virginia, USA.

Baldwin, R. L. and M. J. Allison. 1983. Rumen metabolism. J. Anim. Sci. 57:461-477.

Bryant, M. P. 1973. Nutritional requirements of the predominant rumen cellulolytic bacteria. Fed. Proc. 32:1809-1813.

Carro, M. D. and E. L. Miller. 1999. Effect of supplementing a fibre basal diet with different nitrogen forms on ruminal fermentation and microbial growth in an in vitro semicontinuous culture system (RUSITEC). Br. J. Nutr. 82:149-157.

Cecava, M. J., N. R. Merchen, L. L. Berger and G. C. Fahey, Jr. 1990. Intestinal supply of amino acids in sheep fed alkaline hydrogen peroxide-treated wheat straw-based diets supplemented with soybean meal or combinations of corn gluten meal and blood meal. J. Anim. Sci. 68:467-477.

Chalupa, W. 1976. Degradation of amino acids by the mixed rumen microbial population. J. Anim. Sci. 43:828-834.

Chen, G., H. J. Strobel, J. B. Russell and C. J. Sniffen. 1987. Effect of hydrophobicity on utilization of peptides by ruminal bacteria in vitro. Appl. Environ. Microbial. 53:2021-2025.

Chikunya, S., C. J. Newbold, L. M. Rode, X. B. Chen and R. J. Wallace. 1996. Influence of dietary rumen-degradable protein on bacterial growth in the rumen of sheep receiving different energy sources. Anim. Feed. Sci. Technol. 63:333-340.

Cotta, M. A. and R. B. Hespell. 1986. Proteolytic activity of the ruminal bacterium Butyrivibrio fibrisolvens. Appl. Environ. Microbiol. 52:51-58.

Cruz Soto, R., Samirah A. Muhammed, C. J. Newbold, C. S. Stewart and R. J. Wallace. 1994. Influence of peptides, amino acids and urea on microbial activity in the rumen of sheep receiving grass hay and on the growth of rumen bacteria in vitro. Anim. Feed Sci. Technol. 49:151-161.

Dabrowski, K., K. Lee and J. Rinchard. 2003. The smallest vertebrate, teleost fsh, can utilize synthetic dipeptide based diets. J. Nutr. 133:4225-4229.

Davidson, S., B. A. Hopkins, D. E. Diaz, S. M. Bolt, C. Brownie, V. Fellner and L. W. Whitlow. 2003. Effects of amounts and degradability of dietary protein on lactation, nitrogen utilization, and excretion in early lactation Holstein cows. J. Dairy Sci. 86:1681-1689.

Denman, S. E. and C. S. McSweeney. 2006. Development of a real-time PCR assay for monitoring anaerobic fungal and cellulolytic bacterial populations within the rumen. FEMS Microbiol. Ecol. 58:572-582.

Fu, C. J., E. E. Felton, J. W. Lehmkuhler and M. S. Kerley. 2001. Ruminal peptide concentration required to optimize microbial growth and efficiency. J. Anim. Sci. 79:1305-1312.

Gilbert, E. R., E. A. Wong and K. E. Webb, Jr. 2008. Board-invited review: peptide absorption and utilization: implications for animal nutrition and health. J. Anim. Sci. 86:2135-2155.

Griswold, K. E., G. A. Apgar, J. Bouton and J. L. Firkins. 2003. Effects of urea infusion and ruminal degradable protein concentration on microbial growth, digestibility, and fermentation in continuous culture. J. Anim. Sci. 81:329-336.

Griswold, K. E., W. H. Hoover, T. K. Miller and W. V. Thayne. 1996. Effect of form of nitrogen on growth of ruminal microbes in continuous culture. J. Anim. Sci. 74:483-491.

Hristov, A. N., R. P. Etter, J. K. Ropp and K. L. Grandeen. 2004. Effect of dietary crude protein level and degradability on ruminal fermentation and nitrogen utilization in lactating dairy cows. J. Anim. Sci. 82:3219-3229.

Hu, W. L., J. X. Liu, J. A. Ye, Y. M. Wu and Y. Q. Guo. 2005. Effect of tea saponin on rumen fermentation in vitro. Anim. Feed Sci. Technol. 120:333-339.

Jones, D. F., W. H. Hoover and T. K. Miller Webster. 1998. Effects of concentrations of peptides on microbial metabolism in continuous culture. J. Anim. Sci. 76:611-616.

Kazemi-Bonchenari, M., K. Rezayazdi, A. Nikkhah, H. Kohram and M. Dehghan-Banadaky. 2010. The effects of different levels of sodium caseinate on rumen fermentation pattern, digestibility and microbial protein synthesis of Holstein dairy cows. Afr. J. Biotechnol. 9:1990-1998.

Khafipour, E., S. C. Li, J. C. Plaizier and D. O. Krause. 2009. Rumen microbiome composition determined using two nutritional models of subacute ruminal acidosis. Appl. Environ. Microbiol. 75:7115-7124.

Khalili, H. and P. Huhtanen. 2002. Effect of casein infusion in the rumen, duodenum or both sites on factors affecting forage intake and performance of dairy cows fed red clover-grass silage. J. Dairy Sci. 85:909-918.

Kotzamanis, Y. P., E. Gisbert, F. J. Gatesoupe, J. Zambonino Infante and C. Cahu. 2007. Effects of different dietary levels of fish protein hydrolysates on growth, digestive enzymes, gut microbiota, and resistance to Vibrio anguillarum in European sea bass (Dicentrarchus labrax) larvae. Comp. Biochem. Physiol. A: Mol. Integr. Physiol. 147:205-214.

Lindemann, M. D., G. L. Cromwell, H. J. Monegue, H. Cook, K. T. Soltwedel, S. Thomas and R. A. Easter. 2000. Feeding value of an enzymatically digested protein for early-weaned pigs. J. Anim. Sci. 78:318-327.

Liu, H., L. Wang, L. S. Li and L. B. Wang. 2009. Effects of graded duodenal infusion of soybean small peptides on blood indices, milk composition and mRNA expression of PepT1 in small intestine in lactating goats. Chin. J. Anim. Nutr. 21319-325.

McAllan, A. B. 1991. Carbohydrate and nitrogen metabolism in the forestomach of steers given untreated or ammonia treated barley straw diets supplemented with urea or urea plus fishmeal. Anim. Feed Sci. Technol. 33:195-208.

Newey, H. and D. H. Smyth. 1960. Intracellular hydrolysis of dipeptides during intestinal absorption. J. Physiol. 152:367380.

Pittman, K. A. and M. P. Bryant. 1964. Peptides and other nitrogen sources for growth of Bacteroides ruminicola. J. Bacteriol. 88:401-410.

Puchala, R., S. G. Pierzynowski, T. Wuliji, A. L. Goetsch, T. Sahlu, 
M. Lachica and S. A Soto-Navarro. 2002. Effects of small peptides or amino acids infused to a perfused area of the skin of Angora goats on mohair growth. J. Anim. Sci. 80:1097-1104.

Remond, D., L. Bernard and C. Poncet. 2000. Free and peptide amino acid net flux across the rumen and the mesenteric- and portal-drained viscera of sheep. J. Anim. Sci. 78:1960-1972.

Richardson, C. R. and E. E. Hatfield. 1978. The limiting amino acids in growing cattle. J. Anim. Sci. 46:740-745.

Russell, J. B. and R. J. Wallace. 1997. Energy yielding and energy consuming reactions. In: The Rumen Microbial Ecosystem, Second Ed. (Ed. P. N. Hobson and C. S. Stewart), Springer, Heidelberg, Germany. pp. 246-282.

Russell, J. B., J. D. O'Connor, D. G. Fox, P. J. Van Soest and C. J. Sniffen. 1992. A net carbohydrate and protein system for evaluating cattle diets: I. ruminal fermentation. J. Anim. Sci. 70:3551-3561.

Russi, J. P., R. J. Wallace and C. J. Newbold. 2002. Influence of the pattern of peptide supply on microbial activity in the rumen simulating fermenter (RUSITEC). Br. J. Nutr. 88:73-80.

SAS. 2000. Users guide. Release 8.1 ed. SAS Institute Inc., Cary, $\mathrm{NC}$, USA.

Satter, L. D. 1986. Protein supply from undegraded dietary protein. J. Dairy Sci. 69:2734-2749.

Satter, L. D. and L. L. Slyter. 1974. Effect of ammonia concentration on rumen microbial protein production in vitro. Br. J. Nutr. 32:199-208.

Scholljegerdes, E. J., P. A. Ludden and B. W. Hess. 2004. Site and extent of digestion and amino acid flow to the small intestine in beef cattle consuming limited amounts of forage. J. Anim. Sci. 82:1146-1156.
Skoch, S. A., G. I. Shellig, R. E. Tucker and G. E. Mitchell. 1975. Interactions of amino acid degradation by rumen microbes. J. Anim. Sci. 40(Suppl. 1):197 (Abstr.).

Udén, P., P. E. Colucci and P. J. Van Soest. 1980. Investigation of chromium, cerium, and cobalt as markers in digesta rate of passage studies. J. Sci. Food Agric. 31:625-632.

Van Soest, P. J. 1982. Nutritional ecology of the ruminant. Comstock, Cornell University Press, Ithaca, NY, USA.

Wang, H. R., D.X. Lu, H. Y. Zhang, X. Y. Zhao and Q. Yi. 1998. The study on amino acid digestibility in small intestinal of sheep. Neimengu J. Anim. Sci. 2:18-21.

Webb, K. E., Jr, J. C. Matthews and D. B. DiRienzo. 1992. Peptide absorption: a review of current concepts and future perspectives. J. Anim. Sci. 70:3248-3257.

Williams, A. G. and G. S. Coleman. 1997. The rumen protozoa. In: The Rumen Microbial Ecosystem (Ed. P. N. Hobson and C. S. Stewart). Blackie Academic and Professional Publishers, London. pp. 73-139.

Williams, C. H., D. J. David and O. Iismaa. 1962. The determination of chromic oxide in faeces samples by atomic absorption spectrophotometry. J. Agric. Sci. 59:381-385.

Zhang, B., L. Q. Xue, L. L. Li, Y. G. Chen, G. H. Wen and D. X. Hou. 2007. Effects of soybean small peptides on nitrogen balance, nutrient digestibility and several indices in the portal veinous plasma of goats. Small Ruminant Res. 72:1-10.

Zimmerman, D. R., J. C. Sparks and C. M. Cain. 1997. Carry-over responses to an intestinal hydrolysate in weanling pig diets. J. Anim. Sci. 75(Suppl. 1):71(Abstr.)

Zinn, R. A. and F. N. Owens. 1986. A rapid procedure for purine measurement and its use for estimating net ruminal protein synthesis. Can. J. Anim. Sci. 66:157-166. 